\title{
A REGRA E O JOGO OU MÉTODO E INTERPRETAÇÃO
}

Odone José de Quadros*

SÍNTESE - A necessidade da regra, do método ou de modelos teóricos de referência da interpretação tem suscitado um debate dentro e fora da filosofia - na área das ciências em geral e das ciências humanas - sobre o método como critério de rigor e cientificidade do conhecimento. $\mathrm{Na}$ interpretação, dentro da abordagem da filosofia hermenêutica, se faz a discussão entre método e experiência hermenêutica no âmbito da linguagem. Pretendo apresentar quatro dificuldades e mostrar que onde não há método explicito pode haver rigor e regra e qual é esta autonomia de método. Sobretudo, de como um texto - discurso, obra, tradição - pode ser ele mesmo o critério do processo interpretativo.

PALAVRAS-CHAVE - Método. Interpretação. Acontecer hermenêutico. Jogo. Receptividade e atividade.
ABSTRACT - The need of the rule, of the method or of theoretical models of reference of the interpretation, it has been raising a debate inside and out of the philosophy - in the area of the sciences in general and of the human sciences - on the method as rigidity approach and of scientific character of the knowledge. In the interpretation, inside of the frame of the hermeneutic philosophy, exist the discussion between method and interpretative experience in the field of the language. I intend to present four difficulties and to show that where doesn't have explicit method it can have rigidity and it rules and which is this autonomy of method. Above all, of as a text - proposition, work, tradition - it can be him even the approach of the interpretative process.

KEY WORDS - Method. Interpretation. To hermeneutic happen. Game. Receptivity and activity.

Com a discussão de quatro dificuldades, pretendo abordar a questão da necessidade da regra ou do método, ${ }^{1}$ no bojo do debate sobre a necessidade de modelos teóricos de referência da interpretação, a partir sobretudo do texto de Gadamer, ${ }^{2}$ procurando mostrar porque a experiência interpretativa só acontece para além das regras e como a exigência interpretativa não está no método, mas no texto mesmo. Quando digo para além das regras, quero dizer, pelo menos, para além de regras, modelos e métodos explicitados. ${ }^{3}$ Pretendo também mostrar que

* Doutorando em Filosofia no Curso de Pós-Graduação da PuCRS.

1 STEIN, Ernildo. Instauração do sentido. Porto Alegre: Movimento, 1977, p. 87-109.

2 GADAMER, Hans-Georg. Verdade e método. Traços fundamentais de uma hermenêutica filosófica. Petrópolis: Vozes, 1997.

3 Sobre regras não explicitadas, veja-se mais adiante em Leibniz e Baumgarten; também, em Stein.

\begin{tabular}{|l|l|l|l|l|l|} 
VERITAS & Porto Alegre & v. 44 & n. 1 & Março 1999 & p. 147-165 \\
\hline
\end{tabular}


que acontecer não é um ato misterioso e sagrado, uma coisa secreta, hermética e inefável, mas que é, isto sim, um processo rigoroso e normatizado, só que não por uma norma externa, heteronomia, como a regra do futebol, mas por um rigor interno: autonomia. Agora, é de se perguntar: o que é esta regra interna? De onde vem o rigor ao acontecer? Pretendo mostrar que, neste caso, não é um antes do texto, um anterior ao texto, um fora do texto, uma exterioridade explicitada sob a forma de regra, ou método, ou modelo teórico, um constructo formal, um a prion lógico ao texto que vai decidir sobre o texto ou o sentido do texto, mas o rigor interno ao processo. Pretendo mostrar, portanto, que coisa é esta de "pertença do intérprete a seu texto [...] partindo da base de uma experiência de mundo, constituída lingüisticamente". 4

Minha pretensão não é a de expor o pensamento de Gadamer, nem a de responder às questões que proponho com as respostas de Gadamer, mas a de, questionando a partir do enfoque gadameriano, tentar buscar fundamento para a compreensão dos pontos questionados e, com isto, facilitar o diálogo entre linguagens filosóficas aparentemente intransparentes. O importante não é o autor; (claro que o autor é importante); o importante não é o que o autor quis dizer, (claro que o que o autor quis dizer é importante); o importante é a coerência e a fecundidade do texto, capaz de provocar suas conseqüências. Por isso, o acento principal nunca será no autor, no caso, Gadamer, nem na pura intencionalidade do autor (isto só no primeiro momento de "literalidade", digamos assim, ou de "decifração lógica"5); interessa aqui é a fertilidade da sua proposição, a coerência dela, que é o que gera a possibilidade de seu desenvolvimento na versatilidade e fusão de horizontes.

Não me valho, por isso, só do jargão hermenêutico para tentar esclarecer as posições hermenêuticas. Se ninguém pode criticar a "hermenêutica filosófica" (ou a posição "analítica", ou a "dialética") de fora; será que, quando se trata de aclará-la, esclarecê-la, compreendê-la, explicá-la, quando se trata de uma "decifração filosófica", ${ }^{6}$ a posição endogênica é a melhor?

Por isso, dividi, separei e analisei o que se mostra sem partes, não dissecável, e que só se deixa indicar. Mesmo assim, todo momento analítico só poderá ser apresentado como constituinte do processo sintético. Esta, talvez, a maior dificuldade.

Empregarei os termos texto, obra, discurso, tradição, no enfoque gadameriano, no sentido de interpretandos; interpretação, como experiência hermenêutica; jogo, no sentido da constituição, a um tempo receptiva e ativa, que institui o acontecer ${ }^{7}$ hermenêutico; e verdade, no sentido de acontecer.

4 Gadamer, id., ibid., p. 664 e 665. "Se antes falamos da pertença do intérprete a seu texto, caracterizando a relação que une tradição e historiografia e que se reúne no conceito da consciência da história efeitual, agora podemos determinar mais de perto a pertença, partindo da base de uma experiência do mundo, constituida lingüisticamente."

5 Gauvin, id., ibid., p. 190-196.

6 GAUVIN, J. Filosofia da linguagem. Coimbra: Almedina, 1973, p. 196.

7 STEIN, Ernildo. Aproximaçōes sobre hermenêutica. Porto Alegre: EDIPUCRS, 1996. "Mas o conceito central de Verdade e Método é a expressão experiência" (p. 69). "O fato de que, ao lado da idéia de experiência, o autor usar a expressão acontecer é o que mais choca a tradiçāo analítica e a análise lógica. Que se possa falar, como Gadamer diz, do acontecer da verdade, esse é o grande escândalo 
O método, sob a forma de modelos teóricos, costuma ser apresentado como a garantia do rigor epistêmico, quando não do especulativo, tanto da produção, quanto da interpretação de um discurso. Um conhecimento, um saber, ${ }^{8}$ uma interpretação, apresentam foros de garantia e legitimidade quando amparados e justificados pelos andaimes de um métọdo adequado. No entanto, a estrutura, a sistematicidade, o método, a regração podem até determinar um texto, assim como podem determinar um quadro ou uma estátua, mas não determinam nem a artisticidade da composição destes, nem o sentido daquele.

Quatro dificuldades, a meu parecer, costumam obstaculizar a compreensão da questão aqui proposta. A primeira dificuldade provém da fusão entre método e interpretação, que provoca confusão e impossibilidade de compreensão. Neste caso, interpretar é a aplicação de um modelo teórico e, por isso, é melhor intérprete quem mais exímio na aplicação do método mais adequado. Quem sabe, uma dificuldade não tão presente no campo da filosofia, mas bem mais freqüente na área das ciências humanas ou das "ciências do espírito". Se bem que, em filosofia, há quem discuta se tal ou qual sistema especulativo é método ou tem a ver também com a natureza da realidade.

Quando se afirma a coincidência entre método e interpretação, e que interpretar é aplicar um método sobre o interpretando, tem-se duas coisas: ou que a verdade é método (aplicado), ou que o método é o caminho - hodós - para se extrair a verdade, a mensagem, do discurso. Esta dificuldade se ampara na prévia distinção, melhor, separação entre texto e intérprete. Esta distinção pode tomar as formas também de divisão entre passivo e ativo, ou entre passado e presente, ou entre sujeito e objeto, ou entre externo e interno. Passivo e ativo, porque o "sujeito" é ativo na proposta e aplicação de um método na tarefa ativa de extrair o "o que" do texto ou de "desconstruí-lo"9 para compreendê-lo, e o texto, passivo, é submetido como coisa ou concluso estático a esta investida de possessão ou apropriação cognitiva. Passado e presente, porque, neste caso, nada nos sobrevém, mas desde sempre, ou desde antes, já estava lá: eu é que sobrevim. O texto nos chega do passado sob a forma de passado, isto é, já pronto, e nunca como

da hermenêutica filosófica quando queremos falar nas ciências humanas, nas ciências do espírito. Falar de uma verdade que acontece parece sem sentido, quando no fundo a verdade segundo a tradição analítica é uma propriedade de proposiçōes que podemos estabelecer através de determinados critérios. Sobretudo, analisando a correção da estrutura lógica das proposiçōes e mostrando que elas não apenas fazem sentido, mas são verdadeiras" (p. 71).

8 Emprego, propositadamente, os termos "conhecer" e "saber", ultrapassando a distinção que, às vezes, destes termos se faz.

9 A não ser que se entenda "desconstruir" como Ernildo Stein (Veritas, Porto Alegre, v. 43, n. 1, mar, 1998), quando fala em desconstruir uma expressão: "A desconstrução significa retirar da compreensão e da circulação comum esta expressão e com ela retornar às origens onde ela se gerou. Portanto, desconstruir pode significar despir a expressão de sua universalidade aceita e ressituá-la na nudez e no desamparo de sua origem" (p. 120). Também Gadamer (id., ibid., p. 200, nota 221) "[A estética da recepção, desenvolvida por $\mathrm{H}$. R. Jauss, defendeu este ponto de vista, mas de uma forma tão enfatizada que acaba chegando à indesejada proximidade da dekonstruktion de Derrida. ...." 
possibilidade de ser. ${ }^{10}$ Sujeito e objeto, pela iniludível preeminência ou primazia da consciência sobre o que vem a ela. Externo e interno, porque o "sujeito" é exterior ao texto, no sentido de parcialidade externa e senhor do que ele julga processo de interpretação.

Para fazer coincidir a interpretação com a aplicação de um método, é necessário, portanto, promover a ruptura entre o texto e o intérprete. $\mathrm{O}$ texto é objeto de momentos analíticos, do tipo análise divisiva, onde se identificam as partes submetendo-o ao rigor metodológico, na certeza de que, daí, acabará saltando, como de uma caixa de segredos da qual se conhece a senha, a verdade. Esta dissecação tem mais a ver com a "desconstrução"11 de algo, no sentido comum, do que com um acontecer. $\mathrm{O}$ acontecer hermenêutico não se dá entre as regras e o texto, entre o cognitivo e o fatual, pois é um acontecer que retira fundamento do caráter receptivo e ativo de toda a atualização em finitude. E por atualização em finitude, entendo uma dupla emergência, a do texto e a do intérprete, enquanto nos dois casos se faz presente a constituição fundamental finita do ser humano, constituído lingüisticamente no mundo. Pode-se falar de constituição lingüística da finitude humana no mundo quando no discurso, enquanto palavra, ressoa a finitude; e quando a palavra, ao ser proferida, enquanto linguagem, ressoa uma infinitude, enquanto refere um não dito, e põe em jogo todo um conjunto de possibilidades de sentido. Neste sentido, a linguagem é mais que linguagem. Não a linguagem meramente enquanto léxico e gramática. $\mathrm{E}$ as finitudes que concorrem para o acontecimento da experiência hermenêutica, mais que isso, que a constituem, são, de um lado, "o que nos sobrevém" e, de outro lado, o nós; ou o interpretando e o intérprete.

O conhecimento das regras de um jogo não é o acontecimento do jogo. As regras normatizam; no jogo acontece algo. Quanto ao texto, o conhecimento de modelos teóricos de interpretação, modelos de referência, não podem roubar da obra, ou do texto, o seu caráter de auto-referenciação. Quanto ao intérprete, por outra parte, o conhecimento de metodologias também não faz o intérprete, porque interpretar não é a mera aplicação de regras. Enquanto se estiverem conhecendo as regras, debatendo as regras, não se está jogando; enquanto se estiverem explicitando modelos de referência teóricos não se está interpretando, porque texto e leitor são mais do que as regras e a verdade é mais do que o método. Regra alguma, por si, executa, deixa acontecer, atualiza o que "nos sobrevém e que acontece conosco".

10 HEIDEGGER, Martin. Ser e Tempo. 5. ed. Petrópolis: Vozes, 1995, p. 204. "Interpretar não é tomar conhecimento de que se compreendeu, mas elaborar as possibilidades projetadas na compreensão" (§ 34). STEIN, Emildo. Aproximações sobre hermenêutica. Porto Alegre: EDIPUCRS, 1996: "Na medida em que no compreender está a antecipação de nosso poder ser [...] então essa pertença, essa vinculação com o problema da tradição se torna importante na exposição de Gadamer" ("projeto projetado", p. 71).

11 Veja-se nota n² 9. Também Gadamer (id., ibid., p. 200, nota 221): “[A estética da recepção, desenvolvida por H. R. Jauss, defendeu este ponto de vista, mas de uma forma tão enfatizada que acaba chegando à indesejada proximidade da dekonstruktion de Derrida. ...]" 
A regra aparece, assim, como uma externalidade ${ }^{12}$ ao acontecer hermenêuti$\mathrm{co}$, porque, na interpretação "o decisivo é que ali acontece algo"13 entre o texto, ele mesmo, e o intérprete, ele mesmo, e não entre as regras e o texto. Entre as regras metodológicas e o texto nada pode acontecer além da determinação externa de um a priori metodológico que é imposto ou aplicado por aquele, que, nesta condição de propositor ou seguidor de um método ou modelo teórico apenas, se pensa enganosamente intérprete. Na busca legítima de um instrumento de rigor, revive o pseudo intérprete um momento hegeliano de ato de soberania do espírito sobre as coisas. Na verdade, se havia ele descartado a pertença ${ }^{14}$ ao logos da tradição grega e medieval, como fundamento primeiro que, desde sempre, determina a manifestação da verdade que, pouco a pouco, vinha se deixando possuir progressivamente a cada instante da história; ${ }^{15}$ se havia ele professado a sua incompatibilidade com a priori, transpõe agora para um conjunto normativo de regras ou transporta para o método, para um constructo formal, o a priori que repudiava. Um a priori, sem dúvida, mais condizente com os tempos, porque, aparentemente destituído de caráter ontológico, mas que guarda, no entanto, uma logicidade própria do "paradigma" da consciência. $A$ "fé ingênua no método e na objetividade que este proporciona"16 é antípoda da relação hermenêutica.

Não obstante, as regras se põem, vindas de fora, com aquele caráter da ordem de algo que "fazemos ou que deveríamos fazer", ${ }^{17}$ ou seja, com caráter teórico descritivo ou com caráter teórico prescritivo, normativo, porque se sabe da existência de "leves obstáculos e desvios, condicionados pelos próprios preconceitos." 18

Nenhuma regra é mais exigente do que o texto mesmo. Por isso, a "pertença do intérprete a seu texto"19. O texto é a regra, ele mesmo gera a ordem de sua própria interpretabilidade ou de sua aberta possibilidade de ser interpretado.

Não serão estas afirmativas defensoras do determinismo 20 do texto e da passividade do intérprete? Não se terá apenas virado o lado da gangorra: se não é a

12 Gadamer, id., ibid., p. 669: "Isso não é mais do que um aspecto exterior ao verdadeiro acontecer hermenêutico."

13 Gadamer, id., ibid., p. 669. "O decisivo é que aqui acontece algo."

14 "Na metafísica, pertença quer dizer a relação transcendental entre o ser e a verdade, que pensa o conhecimento como um momento do próprio ser, não primariamente como um comportamento do sujeito. Essa inclusão do conhecimento no ser é pressuposto do pensamento antigo e medieval. O que é, é verdadeiramente por sua essência, isto é, está presente na atualidade de um espírito infinito e, somente por isso, toma-se posșivel ao pensamento humano e finito conhecer o ente" (Gadamer, id., ibid., p. 665).

15 Gadamer, id., ibid., p. 668. A este ponto, Gadamer conclui: "se nossa teoria hermenêutica busca o reconhecimento do entrelaçamento do acontecer e compreender, terá de retroceder não somente até Hegel, mas também até Parmênides".

16 Gadamer, id., ibid., p. 529.

17 Gadamer, id., ibid., p. 14 . "O que está em questão não é o que nós fazemos, o que nós deveriamos fazer, mas o que, ultrapassando nosso querer e fazer, nos sobrevém, ou nos acontece."

18 Gadamer, id., ibid. p. 669.

19 Gadamer, id., ibid., p. 664.

20 Em Stein (Aproximaçöes sobre hermenêutica. Porto Alegre: EDIPUCRS, 1996) aparece certo determinismo quando se refere à consciência histórica efetual: “[...] não há consciência hermenêutica, 
regra, o método, então, é o texto? A par de que esta questão não está colocada com propriedade, pois já se disse, o acontecer não se dá entre o método e a obra, deve-se esclarecer o que significa que o texto, ele mesmo, é a regra. $\mathrm{O}$ que quer dizer Gadamer com "o que está em questão não é o que nós fazemos, o que nós deveríamos fazer, mas o que, ultrapassando nosso querer e fazer, nos sobrevém, ou nos acontece". ${ }^{21} \mathrm{E}$ que os meios metodológicos não são mais do que "um aspecto exterior ao verdadeiro acontecer hermenêutico". ${ }^{22}$

Se, por um lado, nenhuma regra é mais exigente do que o próprio texto, nenhuma regra, por outro, substitui o intérprete. Porque, na verdade, a regra, útil e necessária, não é mais do que uma disposição motivadora e disciplinadora que o próprio intérprete impõe a si mesmo como regime de comportamento ${ }^{23}$ para que não se desvie em "leituras analógicas", ${ }^{24}$ a partir de horizontes ou nichos cristalizados, ou de leituras preconceituosas a partir de pré-juizos ou de projeções, ou de leituras vulgares, destituídas de caráter especulativo, meramente ao nível do ordinário ingênuo.

A segunda dificuldade é aquela de se ficar trancado no dilema de ou dispor de um controle, de regras, de método, de segurança do rigor, ou ficar sem a escada, sem os andaimes e despencar no aleatório, não merecedor da credibilidade filosófica e, portanto, de nenhum critério de "cientificidade". Eis o dilema: ter ou não ter controle; ter ou não ter critério; ter ou não ter regra, método, modelo teórico de referência; ter ou não ter garantia de rigor.

Esta dificuldade se funda ou na conseqüência advinda da primeira dificuldade, ou seja, a de que se não há método, não há interpretação; ou na crença de que só é regra aquela explicitada, identificável e conhecida e que se oferece ao debate da racionalidade científica; ou na concepção de que fora do método não há salvação; ou na posição daquele que, mesmo não admitindo, não conseguiu se libertar do paradigma que diz ter ultrapassado: o da consciência que traz tudo à presença de si mesma no autocontrole da chamada realidade.

Perguntar-se agora se o dilema está entre admitir um controle, o dos modelos de referência metodológica, ou jogar a interpretação ao aleatório, à falta de rigor, desprovendo-a de estatuto filosófico-especulativo e tornando-a não mais que exercício de estranha alogicidade, é uma falácia. O dilema não é o de ter um controle ou não, mas o de qual seja o controle último. ${ }^{25} \mathrm{~A}$ pergunta a ser respondida é

situação hermenêutica, se não existe uma situação histórica efetual quer dizer uma consciência de que nós somos determinados pelos fatos históricos. Esses fatos históricos por um lado, são um peso que limita a nossa compreensão, mas, de outro lado, explicitados, analisados e interpretados passam a ser a própria alavanca do desenvolvimento da compreensão" (p. 71-72).

21 Gadamer, id., ibid., p.14.

22 Gadamer, id., ibid., p. 669.

23 Gadamer, id., ibid., p. 669.

24 Gauvin, id., ibid., p. 183. "O primeiro tipo de decifração é analógico [...]."

25 A propósito, Stein, em Aproximaçōes sobre hermenêutica (Porto Alegre: EDIPUCRS, 1996), afirma: "O acontecer da verdade é um acontecer que não podemos dizer seja um processo anti-metódico, mas é um processo que põe em crítica o método do conhecimento lógico-analítico" (p. 72). E, mais adiante: "Mas se a hermenêutica filosófica trabalha a questão da arte, da história e da linguagem, o sentido, então também ali temos que falar de uma certa semântica. Não uma semântica igual àquela que fundamenta as proposiçōes no nivel lógico-semântico" (p. 72). 
a de que se o método é um subsídio, um momento analítico que o intérprete se põe ele mesmo para "motivar e disciplinar" 26 o seu comportamento de leitura, de interpretação, o organon da interpretação, e que não pode, por isso mesmo, ser o determinante do acontecer hermenêutico, como se poderá dizer que a exigência máxima é o texto mesmo, sem torná-lo agora o determinante da interpretação diante de um intérprete aparentemente passivo? A resposta deve ser procurada no que significa "o decisivo é que ali acontece algo" e o que significa a pertença do intérprete a seu texto". ${ }^{27}$ Mas disto trataremos na terceira dificuldade. Por ora, apenas haverá de nos interessar a questão de como se pode falar de regras ou exigências não explicitadas e de como se pode dizer que nada é mais exigente do que o próprio texto, ou a obra mesma, capaz por si só de gerar a ordem de sua interpretabilidade.

Quero trazer, inicialmente, uma contribuição histórica. E a trago motivado pela citação de Derrida, por Stein, ${ }^{28}$ segundo a qual, a compreensão, o sentido e a interpretação devem se aproximar mais dos recursos da estética do que das regras do Organon. Aparecem aqui as referências à estética e ao Organon.

No século XVIII, no seio da tradição de Christian Wolff, Baumgarten lera Leibniz ${ }^{29}$ que, ao se deter na explicação da idéia clara e distinta cartesiana, admite que às claras se opõem as idéias obscuras, e que às distintas se opõem as confusas. E que assim como há as idéias claras e distintas, há também as claras e confusas. Porque claro é o conhecimento no qual eu tenho como reconhecer a coisa representada; confuso, quando não posso enumerar as características suficientes para, separadamente, discernir uma coisa das outras. E prossegue Leibniz, a partir de um exemplo extraído da arte, afirmando que vemos pintores e outros artistas, bem conhecedores do que é exato e do que é defeituoso, porém, que tantas vezes são incapazes de nos dar alguma razão de seu próprio gosto. Se perguntados, sabem dizer que uma obra não lhes agrada, mas não sabem dizer por quê: porque falta um "não sei quê" à obra (se in re quae displicit desiderare nescio quid) 30

Ora, Baumgarten, ${ }^{31}$ em sua tese de doutorado Aesthetica, inspirado na tradição wolffiana, ao apresentar a oposição radical, estabelecida por Wolff, entre o conhecimento sensível e o conhecimento intelectual, apresentava o primeiro como pars inferior, o conhecimento dos sentidos como o lugar das percepções confusas, enquanto que a pars superior ou racional ele a identificava com o conhecimento claro e distinto da lógica. Mas, e aí a importância de Baumgarten, e para o tema

26 Gadamer, id., ibid., p. 669. "Ele motiva a indispensável disciplina metodológica, com a qual nos comportamos para conosco mesmos."

27 Gadamer, id., ibid., p. 664.

28 Derrida, citado em preleção por Stein, em maio de1998.

29 Leibniz, G. W. Meditationes de cognitione, veritate et ideis. 1684; ed. Erdmann, 1840, I, 79.

30 Leibniz, id, ibid. "Est ergo cognitio vel obscura, vel clara, et clara rursus vel confusa vel distincta [...]. Clara ergo cognitio est, cum habeo unde rem repraesentatam agnoscere possim, eaque rursum est vel confusa, vel distincta. Confusa, cum scilicet non possum notas ad rem ab aliis discernendam sufficientes separatim enumerare [...]. Similiter videmus pictores aliosque artifices probe cognoscere, quid recte, quid vitiose factum sit, ad judicii sui rationem reddere saepe non posse, et quaerenti dicere, se in re quae displicet desiderare nescio quid."

31 BAUMgarTen, A. G.. Estética. Petrópolis: Vozes, 1993. 
de que estamos tratando, se ao conhecimento estético lhe era concedido a nota de claridade própria da esfera lógica e, não obstante, por causa dos sentidos, não The era próprio o caráter de distinto e, por isso, confuso, dever-se-ia admitir que, se ao conhecimento claro e distinto da lógica lhe era próprio as regras do Organon, então o conhecimento claro e confuso deveria ter também as suas regras, embora não conhecidas e não explicitadas, mas tão válidas, efetivas ou exigentes ${ }^{32}$ como as regras conhecidas da lógica. ${ }^{33} \mathrm{Se}$ ao conjunto das regras da lógica se denominava de "Organon", às regras obscuras, não conhecidas mas existentes, do conhecimento sensivel denominou Baumgarten de "Analogon".

Então, já a filosofia do século XVIII, às voltas com o problema do conhecimento, sim, mas nas nascentes da reflexão estética moderna, sabia da existência de regras não explícitas, ou seja, sabia que nem sempre o dilema está entre controle ou nenhum controle, mas na pergunta: que tipo de normatividade. Sabia a segunda metade do século XVIII que regra, método, normatividade, rigor e exigência não eram simplesmente sinônimo de lógica, mas de racionalidade.

E como se entenderá agora que o texto, ele mesmo nos põe em injunção porque possui uma exigente normatividade interna que coincide com o seu dinamismo e a sua capacidade de gerar atualização no șentido acima exposto? Como pode o próprio texto ser o critério de rigor do próprio processo de interpretação. Agora, é de se perguntar: o que é esta regra interna? De onde vem o rigor ao acontecer? Uma regra que não está posta mas que tem que ser descoberta. O rigor the provém da necessidade que o texto - a obra, o discurso, a tradição impõe de ser executado como ele desde sempre exigiu ser, desde a sua origem, enquanto ponto de partida exigente, até o seu êxito singular na interpretação por aquele intérprete. E por executar o texto entendo a experiência de deixar o texto ser, que é o que faz o texto acontecer. Assim, o mesmo rigor, a mesma norma interna que provocou e, por assim dizer, conduziu o processo de produção do texto, de surgimento de um texto, melhor, a mesma norma interna que teve que ser descoberta durante o processo e o conduziu ao êxito da produção, será o rigor e a regra interna que conduzirá a obra, ou o texto, ou o discurso, ao êxito de sua consumação, ou da atualização do seu sentido, na interpretação.

Um discurso, um texto, uma obra surgente nada mais é do que um ponto de partida $^{34}$ exigente de execução. E por executar o texto, repito, entendo a experiência de deixar o texto ser, que é o que faz o texto acontecer. O texto, que ainda

32 Gadamer, id., ibid., p. 105. "[...] a linguagem da arte é uma linguagem exigente, que näo se oferece livre e indeterminada à interpretação que vem da disposição de ânimo, porém, nos fala de uma forma determinada significativamente. E o que há de maravilhoso e misterioso na arte é que essa determinada reivindicação não é, apesar disso, nenhum grilhão para a nossa indole, mas justamente abre o espaço de jogo da liberdade lúdica de nossa capacidade de conhecimento."

33 Stein, a propósito, em Aproximações sobre hermenêutica, afirma: "Mas se a hermenêutica filosófica trabalha a questão da arte, da história e da linguagem, o sentido, entâo também ali temos que falar de uma certa semântica. Não uma semântica igual àquela que fundamenta as proposições no nivel lógico-semântico” (p. 72).

34 PAREYSON, Luigi. ("spunto") Verità e interpretazione. Seconda edizione. Milano: U. Mursia \& C., 1972. (IV edizione), Mursia, Milano, 1991 (I edizione, 1971); Estetica: teoria della formativitá. Terza edizione, Firenze: G.C. Sansoni S.p.A., 1974. Prima edizione, Torino: Biblioteca di Filosofia, 1954. Estética, teoria da formatividade. Petrópolis: Vożes, 1993. 
é um pretexto enquanto ponto de partida, por assim dizer pede ao seu autor que o realize, que o traga à sua realidade, à sua concreção, ao seu acontecimento. Isto năo se faz, de novo, com um ato de soberania do espírito sobre a coisa, mas como uma diligente dialogicidade do autor com o seu ponto de partida, numa conversa de liberdade e fidelidade, de linguagem e ouvir que a compreende, que é o que possibilita a experiência autêntica hermenêutica, ${ }^{35}$ ou numa verdadeira produção que só procura o êxito de si mesma enquanto processo que se instaurou. Por isto se pode dizer que a obra ela mesma se faz e, no entanto, o autor a faz. ${ }^{36} \mathrm{De}$ tal maneira que a maior lei é a legalidade interna do próprio processo de execução do texto.

Esta exigência interna ao processo só se descobre em processo, ou no processo. E só se mostra exitosa no resultado que nunca é o fim do processo, mas que é o processo mesmo gerando agora a injunção em que se põe a liberdade do intérprete diante do texto. A mesma normatividade, controle rígido do processo de execução da produção do texto, se põe agora como garantia do rigor de sua interpretabilidade. Autor e intérprete estão ligados à mesma normatividade interna do texto que, para os dois, não pede senão ser executado, do modo uno como tem que ser executado, não único, e do modo múltiplo, não arbitrário, na leitura, ou na execução da experiência interpretativa. Este périplo que vai da exigência de um ponto de partida acolhida por uma liberdade, até a exigência de ser interpretado, acolhida pelo intérprete, possibilita o acontecer hermenêutico. Deste ponto de vista, não é incongruente afirmar-se que a produção do texto é já uma interpretação e que, a interpretação do texto é também uma produção.

Se é assim, então não é um antes do texto, um anterior ao texto, um fora do texto, uma exterioridade explicitada sob a forma de regra, ou método, ou modelo teórico, um a priori lógico ao texto que vai decidir sobre o texto ou o sentido do texto, mas o rigor interno ao processo. Por isso, dentro da perspectiva processual em que esta abordagem coloca a questão, é destituída de qualquer sentido uma pergunta como esta: tem ou não tem a prior? Se está descartado o a priori do método externo, o a priori da pertença ao logos ou ao ente, o a priori da intencionalidade do autor, o a priori do texto como "coisa", o a priori do "sujeito" como consciência soberana, e tudo está lançado para dentro da dialogicidade processual da autonomia a ser descoberta dentro de cada singular experiência interpretativa, como ainda se pode perguntar por um "a priori"?

E se a regra de autonomia foi seguida, se saberá na interpretação que executa o texto, agora, até a sua consumação ou acontecer. Neste momento interpretativo em que o texto se atualiza em sua execução, no acontecer dialógico do texto com o intérprete, na experiência hermenêutica interpretativa, até as regras não conhecidas se fazem reconhecer no vir a ser do texto. O texto mostra então sua adequação a si mesmo, sua coerência interna, sua economia, sua simplicidade, sua clareza, seu aspecto conseqüente capaz de suscitar o poder ser de sempre novas conseqüências.

35 Gadamer, id., ibid., p. 671.

36 PAREYSON, Luigi. "L'opera si fa da sé eppure la fa l'artista". Estetica: teoria della formatività. Terza edizione, Firenze: G. C. Sansoni S.p.A., 1974. p. 78. 
E não se poderá dizer que a regra externa, abandonada como não-critério de rigor da interpretação, tenha sido transposta para este reconhecimento da regra interna. A regra externa é sempre conhecida, externa e anterior: é um constructo lógico. A regra interna é sempre descoberta, interior e simultânea ao processo: é um achado em processo de dialogicidade entre o texto a ser produzido ou a ser interpretado com o seu autor ou com o seu intérprete. Reconhecê-la não é explicitá-la ou objetivá-la: não há conceituação definida; reconhecê-la não é fechar o processo de interpretação e negar a abertura de possibilidades. Reconhecer, dentro da experiência hermenêutica, é também acontecer. Não havia nada conhecido antes que agora se deixa reconhecer. $\mathrm{O}$ que se impôs como exigência de rigor foi descoberto em processo. Reconhecer, aqui, nunca é o reconhecimento de algo já conhecido, como um método ou as intenções de um autor. ${ }^{37}$

Por isso, se o texto transcende todo o método explicitado, transcende também o próprio autor e pode encontrar em suas interpretações, inovações e "conseqüências" que nem o seu autor pôde alcançar. Por isso, também, a dialogicidade do acontecer não se estabelece entre o intérprete e o autor do texto, em sentido direto, pois isso configuraria uma falácia intencionalista, ou seja, o pressuposto de que o texto, ou a obra, não é nada mais e nada além do que as intenções do seu autor. Neste caso, interpretar seria atrelar a compreensão do texto a uma teleologia presente na vontade intencional do autor. E neste caso, texto, obra, discurso, tradição seriam sinônimos de autor, ou de consciência intencional de um "sujeito". O encontro não seria mais com a obra a ser interpretada, mas entre a consciência do autor e a consciência do intérprete, num esforço do intérprete na decifração de mensagens intencionadas pelo autor. Mas isso não tem nada mais a ver com acontecer hermenêutico e sim com um interpretacionismo lógico.

Por outra parte, perguntar se o reconhecimento do êxito do processo, ou da experiência hermenêutica, ou da "experiência hermenêutica autêntica," 38 daquela em que em cada acontecer a compreensão manifesta a sua "perfeição relativa", 39 perguntar se isto não é a objetivação da regra interna de autonomia, só porque se usou o termo regra, só teria sentido exatamente se houvesse algum a priori, algo já conhecido que viesse a ser reconhecido; ou se o texto fosse tratado como "objeto" determinante. Nem havia nada previamente conhecido, nem o texto é "coisa", "objeto" ao interno da experiência hermenêutica. Tudo é jogado para dentro da descoberta e nunca definidamente explicitável, muito menos definitivamente. Aí, é importante atentar para o que significa "reconhecer", gadamerianamente.

37 Gadamer, id., ibid., p. 192. "O que é o reconhecimento [...] não será compreendido, se somente [...] ali reconhecermos algo que já conhecemos, isto é, o fato de que o conhecido é reconhecido. [...] reside no fato de identificarmos mais do que somente é conhecido." Gadamer, id., ibid., p. 671.

39 Gadamer, id., ibid., p. 682: “[...] A compreensão de um texto transmitido tem uma relação interna essencial com a sua interpretação, e ainda que esta seja, por sua vez, sempre um movimento relativo e inconcluso, a compreensäo alcança nela sua perfeição relativa." 
Uma terceira dificuldade nos vem da compreensão da expressão do que "nos sobrevém ou nos acontece". 40 O que pode estar contido na expressão gadameriana de que "o decisivo é que ali acontece algo"; ou de que "algo nos sobrevém e acontece conosco"; ou na "pertença do intérprete a seu texto"?"1 A dificuldade tem origem seja na concepção de passividade do recebedor, ${ }^{42}$ daquele a quem algo sobrevém ou acontece; seja na noção de cronologia do que chega a nós; seja até mesmo na compreensão da finitude, atrelada, em primeiro lugar, a uma história cronológica que passa. No primeiro caso, na concepção do receptor passivo, a conseqüência é o determinismo do interpretando sobre o intérprete: o texto - a obra - é a regra. No segundo caso, na concepção cronológica de que um antes temporal chega depois a nós, há algo pronto e definido no "antes" e que no seu "depois", que é o agora para nós, tem que ser decifrado. "Ouem está e atua na história faz constantemente a experiência de que nada retorna." 43 No terceiro caso, no modo ordinário e impróprio de compreender a finitude, não há espaço para uma historicidade sem cronologia, um tempo sem tempo e sem a tragicidade daquilo que passa. Finitude, no entanto, inclui uma experiência de receptividade não cronológica, mas que chega à consciência. Finitude que é vista, portanto, não como uma possibilidade de compreensão da existência, entre outras, esquecendose de que é o próprio modo de ser da compreensão que se revela aqui como temporalidade. ${ }^{44}$

Um dia eu me percebi. Quando eu me percebi, quando eu percebi que eu era, percebi, ao mesmo tempo, que eu já era antes de me perceber. Não foi o ato de me perceber que me fez. No começo, me percebo já começado; no princípio, eu já era principiado. Ou seja: no começo eu me recebi. E, receber-me só era possivel enquanto ativamente eu me recebia. Receber só era receber na ação receptiva, não mera receptividade. Receber, portanto, é ação de receber: atividade; e receber é recepção: receptividade. Minha primeira percepção traz consigo "algo que me sobrevém e que acontece comigo": receptividade ativa. Aqui não aparece apenas a estrutura de atividade e receptividade do ser do homem no mundo, mas uma coisa que nos interessa sobremaneira agora. Este "recebido", na ação ativa de receber, não é mero passado, não é mero conteúdo de temporalidade cronológica, não é um puro antes que depois chega, não é coisa pronta que se acolhe, é conteúdo em receptividade, é ação receptiva, é recepção ativa, é dinamismo presente, do modo como ele chega a mim e que só é porque, propiciado pela minha atividade, se faz acontecimento agora. Da mesma forma, como não sou "dono" do meu começo, não o sou também do meu fim. Nas duas pontas aparece a finitude como receptividade porque recebida na minha consciência, ou na compreensão de meu ser. 45

40 Gadamer, id., ibid., p. 14. "O que está em questão não é o que nós fazemos, o que nós deveríamos fazer, mas o que, ultrapassando nosso querer e fazer, nos sobrevém, ou nos acontece" (Ver nota 15).

41 Gadamer, id., ibid., p. 664.

42 Stein, Aproximações... "Gadamer acentua demais o aspecto passivo do acontecer, mesmo então, quando retoma ou afirma a aplicação como o momento do compreender e do interpretar" (p. 80).

43 Gadamer, id., ibid., p. 527.

44 Gadamer, id., ibid., p. 202.

45

Gadamer, id., ibid., p. 415: "Para nós a razão somente existe como real e histórica, isto significa simplesmente: a razão não é dona de si mesma, pois estả sempre referida ao dado no qual se exer- 
O texto não é o texto, coisa ou objeto, ${ }^{46}$ fora do acontecimento interpretativo, nem o intérprete é um "sujeito" fora da experiência da interpretação. Isto significa que o texto e o intérprete só são vistos como tais dentro da situação de receptividade e atividade do ato interpretativo. O jogador não é jogador senão jogando; o jogo não é jogo a não ser ao ser jogado. Um texto fora do acontecer hermenêutico é uma "coisa" que prosaicamente quer dizer alguma coisa; um "sujeito" fora da experiência da interpretação é uma individualidade livre pendurada na história, identificável porque referenciado a estas e estas situações. Dentro do acontecer hermenêutico, no ambiente da linguagem, texto e intérprete, no entreveramento do jogo, são finitudes na experiência de uma infinitude provisória contida no acontecimento. De como finitude e infinitude se encontram reciprocamente na totalidade e na singularidade da experiência hermenêutica, veremos na quarta dificuldade.

Toda a reflexão anterior sobre a não-precedência da regra sobre o texto, ou sobre a finitude do discurso à qual subjaz uma infinitude que se abre na interpretação, nos levou à fronteira contemporânea de que a nossa experiência de mundo é constituída lingüisticamente e que ela nos remete ao conceito de pertença do intérprete ao seu texto, enquanto $\mathrm{o}$ intérprete, finitude aberta a infinitudes de possibilidades, é a consciência que possibilita o acontecer hermenêutico. Agora nos movemos no âmbito da linguagem, no horizonte da lingüisticidade. "Ser que pode ser compreendido é linguagem", diz Gadamer.

Quando o ponto de partida é a linguagem, muda a referenciação do conceito de pertença. O conceito de pertença não é mais determinado nem pela teleologia do ente, ou pela referência à estrutura essencial do ente, assim como aparece na metafísica - falácia essencialista; nem a pertença referenciada ao ente método, ou ao constructo formal que é o método - falácia externalista; nem a pertença determinada pela teleologia das intenções do autor - falácia intencionalista; portanto, nem referenciação ao ente, nem ao método, nem ao autor. Mas também, nem ao texto, enquanto coisa. A auto-referenciação nunca é ao texto, se o texto for entendido como apenas uma coisa, um objeto continente de uma essência, enquanto algo concluso e pronto, mas é à inteireza da experiência hermenêutica pela qual o texto ou algo nos sobrevém e nos acontece. A auto-referenciação não é ao texto enquanto mera coisa, objeto, mas como algo com o que se pode conversar "daí surgindo alguma coisa que nenhum dos interlocutores abarca por si só". ${ }^{47}$ Quando a linguagem passa a ser o Mitte ${ }^{48} \mathrm{em}$ que se realiza a experiência hermenêutica; e com a linguagem, a conversa com a tradição que faz do conhecedor um intérpre-

ce." Também p. 527: "Experiência é, pois, experiência da finitude humana. ...aquele que é consciente desta limitação, aquele que sabe que não é senhor do tempo nem do futuro."

46 Gadamer, id.. ibid., p. 529: "Aquele que compreende a tradição dessa maneira a converte em objeto, e isso significa que se confronta com ela livremente, sem ver-se afetado, e que adquire certeza com respeito ao seu conteúdo, desconectando metodicamente todos os momentos subjetivos de sua relação para com ela."

47 Gadamer, id., ibid., p. 670. "[...] não há um ser em si que se vá revelando cada vez um pouco mais, mas acontece algo como uma verdadeira conversação, dai surgindo alguma coisa que nenhum dos interlocutores abarca por si só."

48 Gadamer, id., ibid., p.662. Centro, ambiente, "frame", âmbito, "meio", "mediu", "modo". 
te, então o fundamento que se põe é completamente outro. "O decisivo", diz Gadamer, "é que aqui acontece algo". 49 Há uma primazia do diálogo (Gespräch).

Se o decisivo é que aqui acontece algo, o que é este "acontecer", visto agora do ponto de vista do intérprete? É uma experiência que não põe o intérprete como um tipo de conhecedor que "busca seu objeto e "extrai" com meios metodológicos" o que ele quer dizer e o que ele realmente é. Por isso, o método, para o acontecer hermenêutico, é um aspecto exterior, ainda que o acontecer hermenêutico suscite disciplina metodológica. "Não obstante", diz Gadamer, "o verdadeiro acontecer só se torna possivel, na medida em que a palavra que chega a nós a partir da tradição, e a qual temos de escutar, nos alcança de verdade, e o faz como se falasse a nós e se referisse a nós mesmos." 50 Gadamer fala de uma "lógica hermenêutica da pergunta", na qual, aquele que pergunta se converte no perguntado, de forma que o acontecer hermenêutico se faz dialética do perguntar. Dialética negativa porque descarta o momento posto pelos preconceitos para 0 acontecer, em abertura fundamental com o texto - obra, discurso, tradição - no âmbito da pergunta-resposta, da dialogicidade..$^{51}$

No âmbito da lingüisticidade, o reconhecimento de que a tradição que nos sobrevém e acontece pode ser uma obra de arte, um fato histórico ou um texto ${ }^{52}$ que foi o termo preferenciado em nossa exposição, permite afirmar que, para Gadamer, o Mitte linguagem não é propriedade única da palavra, do discurso, ou do texto, mas se mostra como aquela enérgheia pela qual significado, sentido e compreensão acontecem, ou na expressão de Humboldt, a linguagem como aquela força do espírito humano pela qual se organiza o pensamento, a nossa experiência interna e o nosso mundo exterior, de tal forma que, o que quer que tenha significado, é no sentido, e pode ser compreendido, e "ser que pode ser compreendido é linguagem".

Do ponto de vista do "objeto" este "acontecer" significa "que o conteúdo da tradição entra em jogo e se desenvolve em possibilidades de sentido e ressonância cada vez novas e ampliadas de modo novo, pelo outro receptor. Quando a tradição volta a falar, emerge algo e entra em cena o que antes não era."53 Os exemplos são apresentados da historicidade da tradição. A tradição pode ser uma obra de arte; pode ser notícias de um grande acontecimento. O que interessa é que a tradição entra na existência como algo que antes não era. Deparar-se, hoje, com a tradição sob a forma de llíada de Homero, ou sob a forma da campanha de Alexandre até a Índia, não é deparar-se com um ser em si e que se vai revelando cada vez um pouco mais nas interpretações históricas; não é deparar-se com um objeto de conhecimento, objetivo e pronto, que nos impõe a sua objetividade, mas

49 Gadamer, id., ibid., p. 669.

50 Gadamer, id., ibid., p. 669 .

51 Stein, Aproximações... "Existe em toda a questão hermenêutica uma espécie de dialética da pergunta e da resposta" (p. 74).

52 Gadamer, id., ibid. "Quando a tradição volta a falar, emerge algo e entra em cena o que antes não era. Qualquer exemplo histórico poderia nos servir para ilustrar isso. Quer a própria tradição seja uma obra de arte, quer proporcione noticias de um grande acontecimento, em qualquer caso, o que se transmite aqui entra de novo na existência, tal como se representa" (p. 669-670).

Gadamer, id., ibid., p. 669. Também a Estética da Recepção, com Jauss, Iser. 
é um acontecimento que tem tudo de diálogo e conversação, que faz surgir alguma coisa que ninguém sozinho, ou que intérprete algum na sua subjetividade, ou que interlocutor algum apanha, abarca e esgota por si só.

Apropriar-se da tradição é interpretá-la, e isto, no acontecer hermenêutico, é um jogo entre o uno, o múltiplo e o sempre aberto que não se esgota em nenhum dos acontecimentos. "A experiência hermenêutica tem a ver com a 'tradição'. É esta que deve chegar à experiência. Todavia, a tradição não é simplesmente um acontecer que se pode conhecer e dominar pela experiência, mas é 'linguagem', isto é, fala por si mesma, como faz um tu. O tu não é objeto, mas se comporta em relação ao objeto. Mas isso não deve ser mal-interpretado como se na tradição o que nela chega à experiência se compreendesse como a opinião de outro, que é um tu. Pelo contrário, estamos convencidos de que a compreensão da tradição não entende o texto transmitido como a manifestação vital de um tu, mas como um conteúdo de sentido, desvinculado de toda atadura para com os que opinam, para com o eu e o tu. Ao mesmo tempo, o comportamento com relação ao tu e ao sentido da experiência que nele tem lugar tem de poder servir à análise da experiência hermenêutica; pois também a tradição é um verdadeiro companheiro de comunicação, ao qual estamos vinculados como o está o eu e o tu." 54

Ou seja, na conversa com o interpretando ou, gadamerianamente, com a tradição, ou ainda, no diálogo histórico com a historicidade e em historicidade, não há a prevalência da consciência do intérprete - a soberania do espírito sobre as coisas; nem a prevalência da consciência do autor; assim como também não há um infinito ou um intelecto infinito que detém e contém a verdade, da qual nós progressivamente vamos nos assenhoreando, na peripécia histórica da tradição. Nem há a prevalência do texto, se este for visto como um objeto portador de uma essência. Há, no entanto, uma autonomia da experiência que, na descoberta de sua novidade em processo, mostra seu rigor próprio o qual, observado, redunda na experiência hermenêutica.

Portanto, diante do texto, do discurso, da obra, da tradição são ultrapassados os conceitos de subjetivo e objetivo: nem a subjetividade, nem a objetividade. A objetividade (Sachlichkeit) da linguagem não é a objetividade (Objektivität) da ciência. A experiência imediata à imediaticidade do ente, presente na linguagem, nunca é a elaboração da ciência que objetiva os entes e os torna disponiveis e calculáveis para fins desejados. Por isso, "constroem-se" teorias na ciência; aqui, fala-se em "desconstrução" do objeto. A infinitude da lingüisticidade da compreensão se entrega na finitude do acontecer lingüístico em que se concretiza em cada caso a compreensão. 55

Também o conceito de pertença adquire um aspecto novo. "Pertencente", diz Gadamer, "é aquilo que é alcançado pela interpelação da tradição". ${ }^{6}$ Imersos em tradições, temos que prestar ouvidos ao que nos chega, a partir delas. Há uma atualização da tradição e a verdade da tradição se abre imediatamente aos sentidos, fazendo-se presente.

54 Gadamer, id., ibid., p. 528.

55 Gadamer, id., ibid., p. 689.

56 Gadamer, op. cit., p. 671. 
Claro que a linguagem não é um modo imediatamente sensivel; e, não obstante, a linguagem é o modo de ser da tradição. Se assim é, então ouvir e compreender envolvem um comportamento lingüístico em relação ao mundo. Por isso, entre tradição e presente, está a comunicação lingüística. Este acontecimento, propiciado pela linguagem e que abre caminho para a compreensão da tradição, é a experiência hermenêutica que assume tudo o que chega ao presente e se the torna presente. Neste sentido, a experiência hermenêutica se faz experiência autêntica. Quando acontece, é um tal tipo de acontecimento que, de um lado, faz com que o acontecido ultrapasse a própria escolha do ouvinte e, também, de outro, que $o$ acontecimento se negue a ser mera repetição de um conteúdo de compreensão, desde sempre dado. O acontecimento hermenêutico não pode deixar que as coisas não aconteçam, por isso nem é livre para estancar o "deixar ser" das coisas, nem para o "fazer ser" das coisas; melhor, não é livre nem para não deixar que as coisas aconteçam, nem para não fazer com que elas aconteçam.

Esta é a estrutura da experiência hermenêutica, tão contrária à idéia metódica da ciência. E esta estrutura típica da experiência hermenêutica encontra seu fundamento na linguagem enquanto acontecimento, ou no caráter de acontecer da linguagem. Pois, repetindo a expressão de Humboldt, ${ }^{57}$ a linguagem é uma força, uma enérgheia do espírito humano, pela qual o homem organiza seu pensamento, sua experiência interior e sua experiência externa de mundo. Assim também, Günter Abel, citado por Stein, ${ }^{58}$ quando afirma que "o dualismo entre linguagem e mundo pode ser superado pela interpretação que não é apenas representação, mas "formação" do mundo". E, com isto, tenta mostrar sua proximidade e sua distância de Gadamer, quando apresenta o seu lema "ser é interpretação", onde se põe, desde um interpretacionismo ontológico, diferente da expressão da hermenêutica filosófica ${ }^{59}$ de Gadamer de que "ser que pode ser compreendido é linguagem".60 Só que é mais do que linguagem-processo, linguagem-meiolingüístico, de quem sabe usá-la e dispõe sobre o seu uso. "Neste sentido", afirma Gadamer, "seria literalmente mais correto dizer que a linguagem nos fala, do que dizer que nós falamos a ela”. ${ }^{61}$ Por isso, mais fácil é se determinar a época em que um texto foi escrito, do que propriamente o seu autor.

Portanto, o importante mesmo é que a linguagem, apenas enquanto léxico, enquanto gramática, enquanto mero processo ou uso lingüístico, não constitui o verdadeiro acontecer hermenêutico. Para Gadamer, até aí se dá a linguagem enquanto linguagem. Sugere, porém, que o acontecimento hermenêutico se dá exatamente enquanto a linguagem é mais do que linguagem: é um mundo, na ex-

57 HUMBOLDT, Wilhelm. Gesammelte Schriften. Akademie-Ausgabe, v. 7, 1. Apud Gadamer, id., ibid. p. 49 .

58 STEIN, Ernildo, A caminho de uma fundamentação pós-metafísica. Porto Alegre: EDIPUCRS, 1997, p. 150, 157. Günter Abel, Mundos da interpretação: a filosofia atual, além do essencialismo e do relativismo. Interpretationswelten - Gegenwartsphilosophie jenseits von Essentialismus und Relativismus. Frankfurt a. M., Suhrkamp, 1993, 560 p.

59 Stein, op. cit., "Filosofia hermenêutica de Heidegger" e "Hermenêutica filosófica de Gadamer", p. 156 e 159

60 Stein, op. cit, p 157.

61 Gadamer, id., ibid., p.672. 
pressão de Pareyson, referindo-se a Dewey. ${ }^{62}$ Isto é, a linguagem que constitui o verdadeiro acontecer hermenêutico é o "vir à fala do que foi dito na tradição, que é ao mesmo tempo apropriação e interpretação". ${ }^{6}$

Apropriação e interpretação, onde se se "deixam as coisas como estão", se faz, contudo, completaria eu referindo-me ao "esforço do conceito", com que elas aconteçam, em nossa receptividade ativa ${ }^{64}$ Se esforço há na construção do conhecimento filosófico, o esforço de fazer, o "esforço do conceito"; 65 este fazer e este esforço não são, no entanto, arbitrários, construídos por projeções subjetivas de idéias que nos ocorram, ou porque nos valemos de idéias preconcebidas, na endogenia do pensamento. Pois, se é verdade, de um lado, que não há acontecimento hermenêutico nenhum sem a nossa consciência, sem o nosso esforço, sem o nosso concurso, o nosso fazer: sem a nossa compreensão; é preciso ter em conta, de outra parte, que "pensar, porém, quer dizer precisamente desenvolver uma coisa em sua própria conseqüência", ${ }^{66} \mathrm{E}$ isto supõe distância das representações "que costumam se interpor" e exige ater-se a um processo de pensar que guarda em si mesmo o seu desenvolvimento e gera a própria ordem de suas conseqüências. Dialética era o nome dado pelos gregos a esta ação do pensamento. "Por isso", pode concluir Gadamer, "é aqui, onde se pode dizer com toda a razão, que esse acontecer não é nossa ação na coisa, mas a ação da própria coisa”. ${ }^{67}$ Já discorremos sobre como um texto contém em si suas conseqüências e de como, o intérprete, sem ser meramente passivo, deixa o texto alcançar sua atualização, isto é, de que forma um discurso se institui com as características de receptividade e atividade, assim como o intérprete.

Este novo status da pertença se deu, desde que Gadamer tomou como ponto de partida a insuficiência do moderno conceito de método, enquanto reflexão externa à coisa mesma e alheia a ela. Claro que desta maneira Gadamer se aproxima da posição hegeliana e da do pensamento clássico. Isto ele mesmo reconhece. Hegel já criticara esta externalidade do método, reportando-se ao conceito grego do método, onde o verdadeiro método apareçe como o fazer da própria coisa. 68

Uma quarta dificuldade decorre da concepção de que o discurso que se dá à interpretação, por seu lado, e o intérprete, por outro, são partes do processo interpretativo que, por sua vez, seria o todo. Cada um, texto e intérprete, entrariam com a sua parte, para o todo da interpretação.

62 PAREYSON, L. I problemi dell' estetica. Seconda edizione riveduta, Milano: Marzorati Editore, 1966. p. 45, "un mondo", citando Dewey "l'arte è sempre piú che arte". Os problemas da estética. São Paulo: Martins Fontes, 1985.

63 Gadamer, id., ibid., p. 672.

64 Gadamer, id., ibid., p. 672. "O verdadeiro método seria o fazer da própria coisa (Hegel, Logik II, p. 330 (Meiner). Naturalmente esta afirmação não quer dizer que o conhecimento filosófico não seja também um fazer que requer seu esforço, o "esforço do conceito".

66 Gadamer, id., ibid., p. 672.

67 Gadamer, id., ibid., p. 672.

67 Gadamer, id., ibid., p. 672.

68 Hegel, Logik II, p. 330 (Meiner). Apud Gadamer, id., ibid., p. 672. 
Nem partes interpretam um todo, porque nem intérprete e interpretando . partes, nem se interpretam partes de um todo. Todos são uma completude, ${ }^{69}$ ur inteireza, no todo do processo interpretativo e, contudo, só o são pela sua singu laridade. Este "todo" tem um caráter de "per-acabado", do latim perficere - perfectum, completamente acabado em cada singular acontecer; ${ }^{70}$ e não apenas de "feito", do latim facere - factum. Não é como o cerne de uma árvore que tem a sua casca sempre em modificação. Pois nem o texto é um cerne de conteúdo permanente que se entrega nas cascas mutantes das interpretações, nem existe um cerne prévio ou permanente que possibilita o jogo interpretativo. Não há um núcleo permanente que se entrega ou que nos sobrevém a cada interpretação. ${ }^{71} \mathrm{~A}$ única coisa permanente é a possibilidade de compreensão ou o fundo dentro do qual, desde sempre, é possível interpretar. E assim mesmo, este fundamento permanente só se mostra permanente, ou só mostra que é permanente, na provisoriedade do acontecer ou da experiência hermenêutica. ${ }^{72} \mathrm{~A}$ enérgheia só se mostra no ergon. ${ }^{73}$

Na interpretação não há cerne permanente, nem casca provisória. Tudo, de certa forma, é provisório e permanente, enquanto o horizonte de compreensão, dentro do qual, desde sempre estamos jogados e que possibilita o jogo de sentido na linguagem, só se dá na provisoriedade deste ou daquele singular acontecer, quando o interpretando nos sobrevém e chega a nós e algo ali, na totalidade e na singularidade, acontece. A totalidade do processo interpretativo só se dá pela singularidade do texto e do intérprete. A experiência hermenêutica é sempre de totalidade, mas, enquanto acontecer, de totalidade provisória. "O esforço hermenêutico tem como tarefa pôr a descoberto um todo de sentido na multilateralidade de suas relações. À totalidade das determinações do pensamento, corresponde a individualidade de sentido a que se tem em mente."74 Há uma experiência humana de ordem geral - de universalidade, de permanência, propiciada por uma experiência humana de ordem particular - de singularidade, de provisorieda-

69 Gadamer, id., ibid., p. 618: "Nenhuma palavra humana pode expressar nosso espirito de uma maneira perfeita. Todavia, [...] isso não é a imperfeição da palavra como tal. A palavra reproduz de fato e por completo aquilo a que o espírito intenciona. Antes, a imperfeição do espirito humano consiste em que não possui jamais uma autopresença completa, mas que está disperso, tendo em mente uma vez isso, outra, aquilo. [...] por necessidade, muitas palavras diferentes. A multiplicidade das palavras não significa, pois, de modo algum, que em cada palavra exista alguma deficiência que pudesse ser superada [...] Ao contrário, porque nosso intelecto é imperfeito, isto é, não é inteiramente presente a si mesmo naquilo que sabe, tem necessidade de muitas palavras. Não sabe realmente o que sabe."

70 Gadamer, id., ibid., p. 682: "[...] A compreensăo de um texto transmitido tem uma relação interna essencial com a sua interpretação, e ainda que esta seja, por sua vez, sempre um movimento relativo e inconcluso, a compreensão alcança nela sua perfeição relativa."

71. Gadamer, id., ibid., p. 670. "[...] não há um ser em si que se vá revelando cada vez um pouco mais, mas acontece algo como uma verdadeira conversação, daí surgindo alguma coisa que nenhum dos interlocutores abarca por si só".

72 Gadamer, id., ibid., p. 188. "Categorialmente visto, toda a modificação (alloiosis) pertence ao âmbito da qualidade, isto é, um acidente da substância. A transformaçāo, ao contrário, significa que algo, de uma só vez e no seu conjunto, se torna uma outra coisa, de maneira que essa outra coisa, que é enquanto transformada, passa a ser seu verdadeiro ser, em face do qual seu ser anterior é nulo."

73 Gadamer, id., ibid., p. 187.

74 Gadamer, id., ibid., p. 683. 
Nem partes interpretam um todo, porque nem intérprete e interpretando são partes, nem se interpretam partes de um todo. Todos são uma completude, ${ }^{69}$ uma inteireza, no todo do processo interpretativo e, contudo, só o são pela sua singularidade. Este "todo" tem um caráter de "per-acabado", do latim perficere - perfectum, completamente acabado em cada singular acontecer; ${ }^{70}$ e não apenas de "feito", do latim facere - factum. Não é como o cerne de uma árvore que tem a sua casca sempre em modificação. Pois nem o texto é um cerne de conteúdo permanente que se entrega nas cascas mutantes das interpretações, nem existe um cerne prévio ou permanente que possibilita o jogo interpretativo. Não há um núcleo permanente que se entrega ou que nos sobrevém a cada interpretação. ${ }^{71} \mathrm{~A}$ única coisa permanente é a possibilidade de compreensão ou o fundo dentro do qual, desde sempre, é possível interpretar. $\mathrm{E}$ assim mesmo, este fundamento permanente só se mostra permanente, ou só mostra que é permanente, na provisoriedade do acontecer ou da experiência hermenêutica. ${ }^{72} \mathrm{~A}$ enérgheia só se mostra no ergon. ${ }^{73}$

$\mathrm{Na}$ interpretação não há cerne permanente, nem casca provisória. Tudo, de certa forma, é provisório e permanente, enquanto o horizonte de compreensão, dentro do qual, desde sempre estamos jogados e que possibilita o jogo de sentido na linguagem, só se dá na provisoriedade deste ou daquele singular acontecer, quando o interpretando nos sobrevém e chega a nós e algo ali, na totalidade e na singularidade, acontece. A totalidade do processo interpretativo só se dá pela singularidade do texto e do intérprete. A experiência hermenêutica é sempre de totalidade, mas, enquanto acontecer, de totalidade provisória. "O esforço hermenêutico tem como tarefa pôr a descoberto um todo de sentido na multilateralidade de suas relações. À totalidade das determinações do pensamento, corresponde a individualidade de sentido a que se tem em mente."74 Há uma experiência humana de ordem geral - de universalidade, de permanência, propiciada por uma experiência humana de ordem particular - de singularidade, de provisorieda-

69 Gadamer, id., ibid., p. 618: "Nenhuma palavra humana pode expressar nosso espírito de uma maneira perfeita. Todavia, [...] isso não é a imperfeição da palavra como tal. A palavra reproduz de fato e por completo aquilo a que o espírito intenciona. Antes, a imperfeição do espírito humano consiste em que não possui jamais uma autopresença completa, mas que está disperso, tendo em mente uma vez isso, outra, aquilo. [...] por necessidade, muitas palavras diferentes. A multiplicidade das palavras não significa, pois, de modo algum, que em cada palavra exista alguma deficiência que pudesse ser superada [...] Ao contrário, porque nosso intelecto é imperfeito, isto é, não é inteiramente presente a si mesmo naquilo que sabe, tem necessidade de muitas palavras. Não sabe realmente o que sabe."

70 Gadamer, id., ibid., p. 682: “[...] A compreensão de um texto transmitido tem uma relação interna essencial com a sua interpretação, e ainda que esta seja, por sua vez, sempre um movimento relativo e inconcluso, a compreensão alcança nela sua perfeição relativa."

71 Gadamer, id., ibid., p. 670 . "[...] não há um ser em si que se vá revelando cada vez um pouco mais, mas acontece algo como uma verdadeira conversação, daí surgindo alguma coisa que nenhum dos interlocutores abarca por si só".

72 Gadamer, id., ibid., p. 188. "Categorialmente visto, toda a modificação (alloiosis) pertence ao âmbito da qualidade, isto é, um acidente da substância. A transformação, ao contrário, significa que algo, de uma só vez e no seu conjunto, se torna uma outra coisa, de maneira que essa outra coisa, que é enquanto transformada, passa a ser seu verdadeiro ser, em face do qual seu ser anterior é nulo."

73 Gadamer, id., ibid., p. 187.

74 Gadamer, id., ibid., p. 683. 
de, no texto e no intérprete, a cada acontecer hermenêutico. Há uma totalidad permanente que só se dá, ou que só é, na experiência da provisoriedade, na qua os horizontes ${ }^{75}$ dentro dos quais estão obra e intérprete podem se encontrar e qu é o que, desde sempre, possibilita a experiência hermenêutica da compreensão da interpretação, do acontecer, no Mitte da linguagem.

No acontecer hermenêutico, não se jogam partes, são totalidades que possi bilitam a experiência hermenêutica. O texto - a obra, o discurso, a tradição uma totalidade receptiva e ativa e o intérprete é uma totalidade receptiva e ativa Só desta forma se pode compreender como um discurso uno não é único e se fa: múltiplo e não arbitrário, não completamente outro, na ação receptiva do intér prete. Unidade do que nos sobrevém não é unicidade. Multiplicidade das inter pretações não é arbitrariedade. Isto é resguardado pelo caráter de totalidade pro visória das singularidades constituintes do acontecimento hermenêutico ou inter pretativo.

Assim, podemos falar do uno e do múltiplo, do todo e da parte, do universal । do singular, da finitude e da infinitude, da pessoalidade - "subjetividade" - e di impessoalidade - "objetividade" - dentro de duas perspectivas que, em verdade são uma só: na perspectiva da experiência hermenêutica ou do acontecer e ni perspectiva da linguagem como Mitte ou da lingüisticidade. Porque, dentro di acontecer hermenêutico, no ambiente da linguagem, texto e intérprete, no entre veramento do jogo, são finitudes na experiência de uma infinitude provisória con tida no acontecimento. Finitudes num processo de acontecimento dentro da ex periência recíproca receptiva e ativa, dentro do encontro de mútuo abandono , posse. Infinitude da virtualidade viva da linguagem que, "sem poder dizê-lo intei ramente, põe em jogo todo um conjunto de sentido"76 entregue às suas conse qüências e interpretações; infinitude, enquanto a linguagem traz a experiência $d^{\prime}$ mundo, mediando "a essência histórico-finita do homem consigo mesmo e com , mundo"; infinitude, pela referência da linguagem ao todo dos entes. Por isso, todı o encontro com a linguagem de um texto, de uma obra, ou da tradição, é un encontro com um acontecimento não acabado, ou com uma totalidade nunci acabada, e a linguagem mesma está contida nesse acontecimento. ${ }^{77}$

Por fim, não se poderá dizer que conhecer é já um acontecer. Pois, se se podi dizer que todo o acontecer é sempre, de algum modo, conhecimento, não se podı dizer que todo o conhecer é, da mesma forma, um acontecer, no sentido her menêutico, e isto enquanto atitude do conhecedor, não enquanto possibilidade d

75 GADAMER, H. Horizonte; fusão de horizontes. " $\mathrm{O}$ âmbito de visão que abarca e encerra tudo que visivel a partir de um determinado ponto". (Verdad y metodo I, p. 372-373).

Gadamer, id., ibid., p. 664: "A ocasionalidade do falar humano não é uma imperfeição eventual d sua capacidade expressiva, mas, antes expressão lógica da virtualidade viva do falar que, sem pc der dizê-lo inteiramente, põe em jogo todo um conjunto de sentido. Todo falar humano é finito n sentido de que, nele, jaz uma infinitude de sentido a ser desenvolvida e interpretada." Também $(r$ 663): "A linguagem não é o indício da finitude porque exista a diversidade de estruturaçảo da lir. guagem humana, mas porque toda a lingua está em constante formação e desenvolvimento, quant mais trouxer à fala a sua experiência do mundo. [...] Somente o 'mediu' da linguagem, por sua re ferência ao todo dos entes, pode mediar a essência histónico-finita do homem consigo mesmo com o mundo."

77 Gadamer, id., ibid., p. 171. 
compreensão. Do que se depreende a diferença entre uma interpretação lógica, que não é um acontecer, presente em correntes interpretacionistas do tipo de Lenk, ${ }^{78}$ onde se preferencia o cognitivo e o metodológico, e o acontecer hermenêutico que faz do conhecedor um intérprete, onde a preferenciação é a do próprio acontecer, no ambiente da lingüisticidade, e onde a linguagem é mais do que linguagem, é um mundo. Isto significa, onde conhecimento e linguagem são para além da semântica igual àquela que fundamenta as proposições no nível lógico-semântico, isto é, para além do dicionário, para além do imediato significado lógico e semântico do discurso. "Somente porque, entre aquele que compreende e seu texto, não existe uma concordância lógica e natural, é que se pode vir a participar, no texto, de uma experiência hermenêutica."79

\section{Referências bibliográficas}

BAUMGarten, A. G.. Estética. Petrópolis: Vozes, 1993.

GADAMER, Hans-Georg. Verdade e método. Traços fundamentais de uma hermenêutica filosófica. Petrópolis: Vozes, 1997.

GAUVIN, J. Filosofia da linguagem. Coimbra: Almedina, 1973.

HEIDEGGER, Martin. Ser e tempo. 5. ed. Petrópolis: Vozes, 1995.

LEIBNIZ, G. W. Meditationes de cognitione, veritate et ideis. 1684; ed. Erdmann, 1840, I, 79.

PAREYSON, Luigi. Verità e interpretazione. 2. ed. Milano: U. Mursia \& C., 1972. (IV edizione, Mursia, Milano, 1991; I edizione, 1971).

- Estetica: teoria della formatività. 3. ed. Firenze: G.C. Sansoni S.p.A., 1974. Prima edizione,

Torino: Biblioteca di Filosofia, 1954.

STEIN, Emildo. A caminho de uma fundamentação pós-metafísica. Porto Alegre: EDIPUCRS, 1997.

. Aproximações sobre hermenêutica. Porto Alegre: EDIPUCRS, 1996.

. Instauração do sentido. Porto Alegre: Movimento, 1977.

78 LENK, Hans. Interpretationskonstrukte - Zur Kritik der Interpretatorischen Vernunft. Frankfurt a. M.: Suhrkamp, 1993, 698 p. In: Stein, A caminho..., p. 150-160. "Tudo o que, como seres que conhecem e agem, nós podemos conceber e apresentar depende de interpretação" (Stein, id., ibid., p. 153). "Interpretacionismo transcendental". "Interpretacionismo metodológico". "Teoria pragmática do conhecimento". "Interpretacionismo pragmático da constituição". "Impregnação de interpretação."

79 Gadamer, id., ibid., p. 683. 